\title{
Comparative Assessment of Wear Indicators in Grinding Discs During Grinding of Selected Steels
}

\author{
Jerzy Józwik ${ }^{1, *}$, Ivan Kuric $^{2}$, and Andrzej Łukaszewicz ${ }^{3}$ \\ ${ }^{1}$ Lublin University of Technology, 36 Nadbystrzycka Street, 20-618 Lublin, Poland \\ ${ }^{2}$ University of Zilina, 8215/1 Univerzitna Street, 01026 Zilina, Slovak Republic \\ ${ }^{3}$ Bialystok University of Technology, 45 Wiejska Street, 15-351 Białystok, Poland
}

\begin{abstract}
In the paper basic experimental tests were carried out to compare the wear indicators of selected abrasive grinding discs in grinding process of steel. Experimental tests on the wear and efficiency of metal grinding discs were made for four types of steel (S235, NC6, Hadfield steel, WNLV + QT steel). The wear parameter included in the ISO standard $(\mathrm{KG})$ of new abrasive discs from European market were examined. This paper presents an analysis of the efficiency and wear of the company's „MOST” grinding discs using an angle grinder.
\end{abstract}

\section{Introduction}

Cutting is the primary means of separating the material. This process is being studied by many researchers [1-7]. Special interest concern the process of wear of the cutting discs and their reducing [8-25]. Cutting discs are mostly assembled for angle grinders. To use the right cutting disc for specific work we must consider the type of material to be treated [1-5]. Thus, soft materials should be treated with hard grinding discs and hard materials should be treated with soft discs. The hardness of cutting discs is influenced by the type of abrasive grain used and the type of binder used [16-25]. Modeling of the cutting processes allows to optimize the selection of tools, their parameters and technological conditions [8-15]. Among the abrasive grains, you can highlight the grain of natural origin, that is [1]: diamond, corundum, emery. The abrasive grains of artificial origin include: electrocorund, silicon carbide, borazone, artificial diamond, boron carbide. The impact of abrasive grains on the object can be divided into three stages $[8,11]: 1)$ elastic deformation and friction between the grain and the workpiece, 2) the decoherence of microfragments of the workpiece and the formation of chips, 3) removal of chips. The contribution of each of the stages depends on the properties of the workpiece, grinding parameters, friction conditions and the geometry of the abrasive grains [2, 11, 26-29].

As a result of friction, large amounts of heat are generated [20, 23]. This causes a significant increase in the temperature of the surface and its structural changes. Among the negative effects of thermal impact during the cutting process, one may point to scorching of the surface layer, phase changes of the material, softening with the possibility of multiple

\footnotetext{
*Corresponding author: j.jozwik@pollub.pl
} 
curing of the surface layer, unfavorable residual tensile stress, grinding cracks and reduced fatigue strength $[4,20,26]$. Typically, during a classical cutting process to eliminate these negative effects, a properly selected coolant is used along with the appropriate method of dosing and flow rate $[3,31]$. However, when cutting using a power tool it is cooled with air. This results in intense and significant changes in the shape and dimensions of the tool due to its wear, increased heat affected zones, structural changes due to high temperature. As a result, there is a reduction in the efficiency of the cutting operation [16-26].

Computer-Aided Technologies (CAx) are extensively used in mechanical engineering field [30-32]. The main advantage of using CAx systems is a shortening of the product's time development. The ability to perform several types of CAE analyses [33-35] leads to obtain a better product. The applications of CAx systems used in manufacturing and CNC branch are outlined in many papers [30-36].

\section{Experimental environment}

In order to compare the operational characteristics of selected types of abrasive grinding wheel (manufacturer: MOST company), experimental tests of wear and performance parameters of discs during grinding of selected construction materials were carried out.

(a)

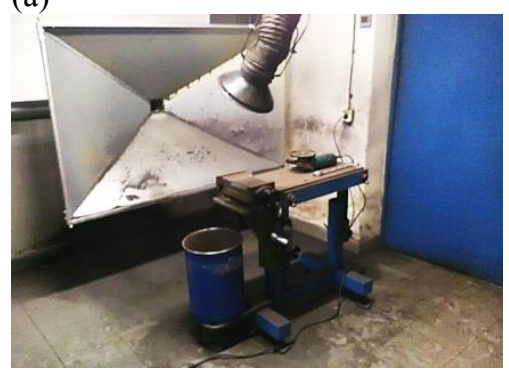

(c)

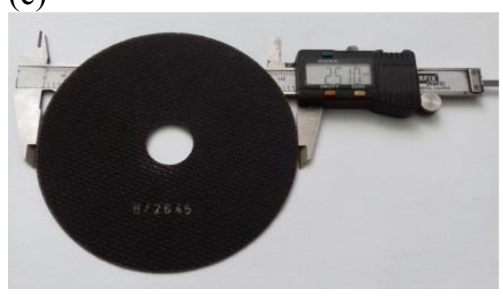

(b)

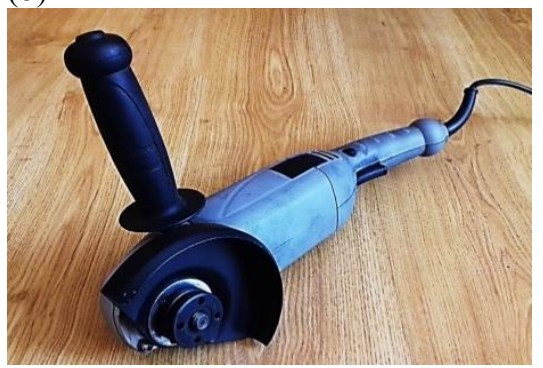

(d)

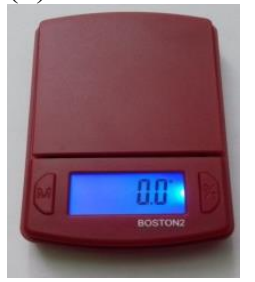

(e)

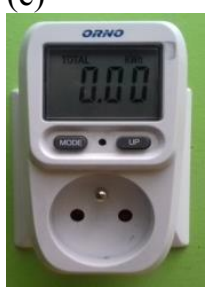

Fig. 1. Test stand for testing abrasive cutting discs: a) table with lift, b) hand grinder, c) electronic caliper (accuracy $0,01 \mathrm{~mm}$ ), d) balance to measure the mass of the abrasive cutting wheel and the workpiece (accuracy $0,1 \mathrm{~g}$ ), e) electricity consumption meter (accuracy $0,01 \mathrm{kWh}$ ).

The tests were carried out under identical technological conditions, determined on the basis of preliminary research. The test stand is a table with handles for stable fixing of the workpiece (Fig. 1a). During the tests, an angle grinder with a power of $1400 \mathrm{~W}$ was used (Fig. 1b). The tests included measuring the diameter of grinding discs (Fig. 1c). Diameter measurements of grinding discs were made in four places every $45^{\circ}$ before and after the tests. As a result, the arithmetic mean of four measurements was taken. The weight of the workpiece and the weight of the grinding wheel were also measured using an electronic balance (Fig. 1d). The meter was used to measure the electricity consumed by the grinder (Fig. 1e).

The paper included analysis of the grinding process and quantitative assessment of grinding discs wear on the basis of disc diameter changes during cutting, evaluation of 
grinding performance based on time measurement and dimensionless KF coefficient. Grinding process analysis was also carried out. Estimation of $\mathrm{KG}$ coefficient and evaluation of efficiency obtained during 15 minutes of grinding were carried out.

\section{Test parameters during the cutting process}

Experiment of grinding process were carried out on four plates (each $20 \times 400 \times 200$ ) made of steels: S355, NC6, Hadfielda steel, WNLV + QT (Fig. 2).

(a)

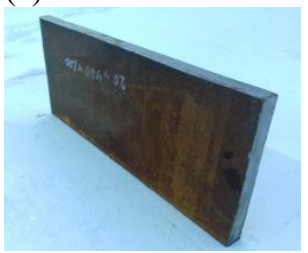

(b)

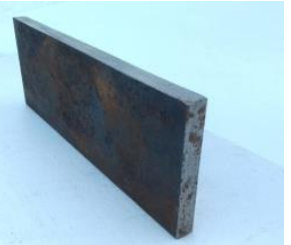

(c)

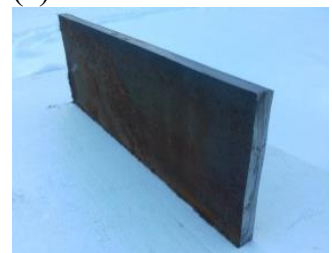

(d)



Fig. 2. Plates with dimensions $20 \mathrm{~mm}$ x $400 \mathrm{~mm}$ x 200mm, made of: a) S355 steel, b) NC6 steel, c) Hadfield steel, d) WNLV + QT steel.

Nine different grinding wheels were used for the tests. The specificity of individual grinding wheels are presented in Table 1 (named as: wheel A, wheel B, .. wheel I).

Table 1. Specification of grinding wheels used during grinding tests.

\begin{tabular}{|c|c|c|}
\hline Gin & $\begin{array}{l}\text { wheel A: } \\
\mathrm{D}_{1}=125 \mathrm{~mm}, \\
\mathrm{~h}=6,5 \mathrm{~mm}, \\
\text { electrocorund, } \\
\text { reinforced resin binder, } \\
\mathrm{g}=0,85 \mathrm{~mm}-0,71 \mathrm{~mm} \\
\text { hard grinding wheel }\end{array}$ & $\begin{array}{l}\text { wheel B: } \\
\mathrm{D}_{1}=125 \mathrm{~mm}, \\
\mathrm{~h}=6,5 \mathrm{~mm}, \\
\text { electrocorund, } \\
\text { reinforced resin } \\
\text { binder, } \mathrm{g}=0,71 \mathrm{~mm}- \\
0,6 \mathrm{~mm} \\
\text { hard grinding wheel }\end{array}$ \\
\hline & $\begin{array}{l}\text { wheel C: } \\
\mathrm{D}=125 \mathrm{~mm}, \\
\mathrm{~h}=6,8 \mathrm{~mm}, \\
\text { electrocorund, } \\
\text { reinforced resin binder, } \\
\mathrm{g}=0,85 \mathrm{~mm}-0,71 \mathrm{~mm} \\
\text { very hard grinding } \\
\text { wheel }\end{array}$ & $\begin{array}{l}\text { wheel D: } \\
\mathrm{D}_{1}=125 \mathrm{~mm}, \\
\mathrm{~h}=6,5 \mathrm{~mm}, \\
\text { electrocorund } \\
\text { reinforced resin } \\
\text { binder, } \\
\mathrm{g}=0,85 \mathrm{~mm}- \\
0,71 \mathrm{~mm} \\
\text { very hard grinding } \\
\text { wheel }\end{array}$ \\
\hline 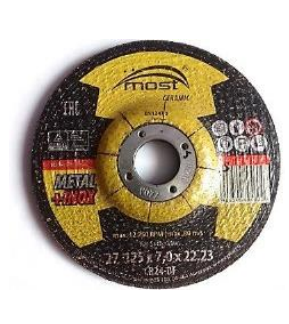 & $\begin{array}{l}\text { wheel E: } \\
\mathrm{D}_{1}=125 \mathrm{~mm}, \\
\mathrm{~h}=7,0 \mathrm{~mm}, \\
\text { chromium } \\
\text { electrocorund, } \\
\text { reinforced resin binder, } \\
\mathrm{g}=0,85 \mathrm{~mm}-0,71 \mathrm{~mm}, \\
\text { very hard grinding } \\
\text { wheel }\end{array}$ & $\begin{array}{l}\text { wheel F: } \\
\mathrm{D}_{1}=125 \mathrm{~mm}, \\
\mathrm{~h}=7,0 \mathrm{~mm}, \\
\text { electrocorund, } \\
\text { reinforced resin } \\
\text { binder, g= } 0,6 \mathrm{~mm}- \\
0,5 \mathrm{~mm}, \\
\text { hard grinding wheel }\end{array}$ \\
\hline
\end{tabular}




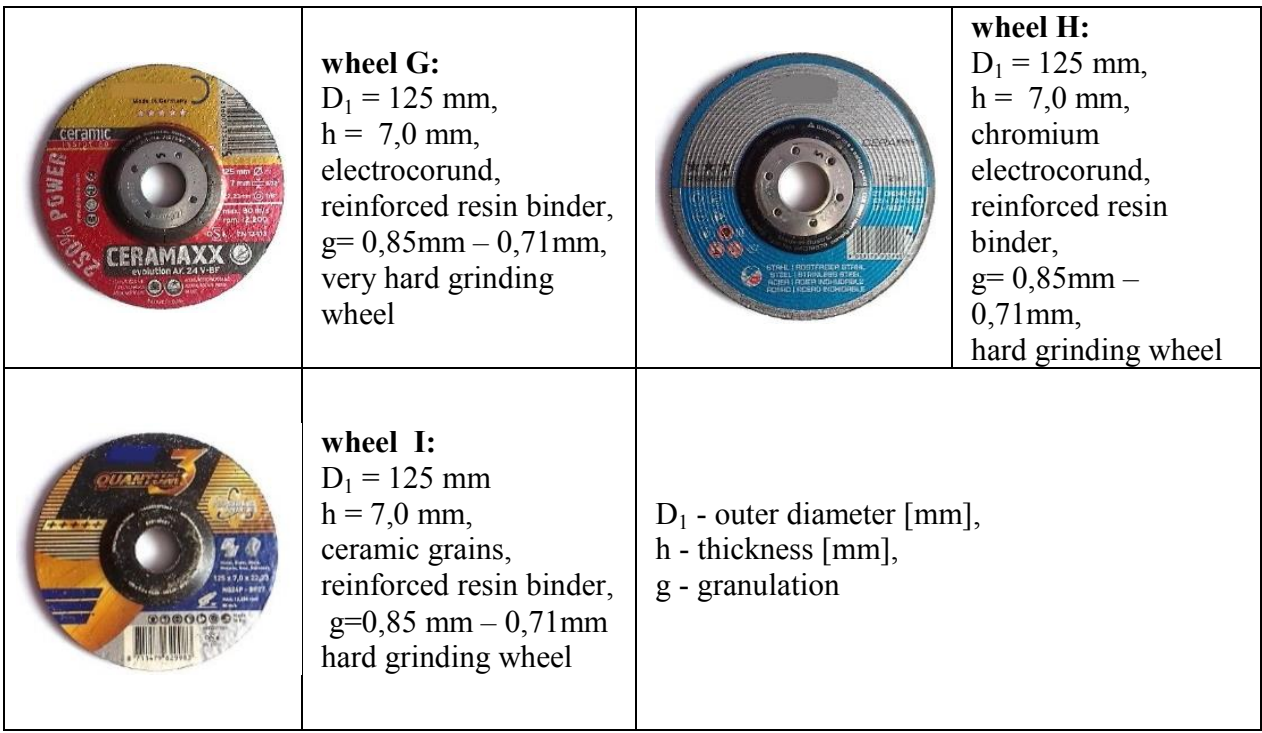

Prior to the tests, the grinding wheel mass and the weight of the workpiece were measured. Then, the grinding wheel was placed on the spindle of the grinder, while the workpiece was mounted on the table. Between the power socket and the grinder plug there is a meter of electricity consumption to monitor its consumption. After performing these activities, the grinding process was started. The time of the grinding process was constant and was 15 minutes for each workpiece. After finishing the grinding process, the weight of the workpiece and the grinding wheel were measured again. On this basis, the grinding coefficient $\mathrm{KG}$ of wheel was determined from equation (1).

$$
\mathrm{KG}=\frac{m_{\mathrm{m} 1}-m_{\mathrm{m} 2}}{m_{\mathrm{s} 1}-m_{\mathrm{s} 2}}
$$

when: $\mathrm{m}_{\mathrm{m} 1}$ - the workpiece mass before grinding $[\mathrm{g}], \mathrm{m}_{\mathrm{m} 2}$ - the workpiece mass after grinding $[\mathrm{g}], \mathrm{m}_{\mathrm{s} 1}-$ the wheel mass before grinding $[\mathrm{g}], \mathrm{m}_{\mathrm{s} 2}$ - the wheel mass after grinding [g].

\section{Results}

Based on the results of the tests (Fig. 3), it was found that the grinding wheels E, F, G, H and I are characterized by similar treatment efficiency of selected types of steel. Their efficiency is significantly higher than the other four grinding wheels. Grinding wheels A, B, $\mathrm{C}$ and $\mathrm{D}$ are characterized by similar machining efficiency, but for WNLV steel and Hadfield steel the efficiency of the first one is the lowest. The tests show that steel S355 is the most susceptible from abrasion. The best resistance to abrasion is characterized by WNLV steel and Hadfield steel, which according to the results obtained were similar. When machining Hadfield steel, the best performance was demonstrated by the grinding wheel F, because for 15 minutes of grinding it clogged $875 \mathrm{~g}$ of this steel, while for S355 steel the best efficiency was obtained for grinding wheel I, it is $1155 \mathrm{~g}$ of ground steel.

The KG grinding coefficient during wheel tests is presented in Fig. 4. This coefficient expresses the relative grinding efficiency and is defined as the mass value of the ground material for the grinding wheel used for this purpose. The higher the value of this coefficient, the greater the capacity of the grinding wheel. 


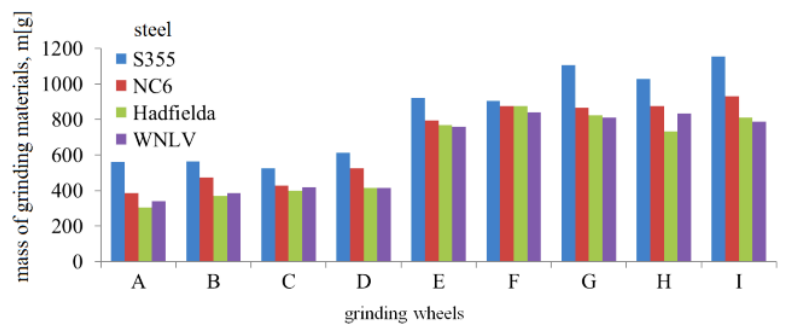

Fig. 3. Efficiency of grinding wheels obtained during 15 minutes of grinding.

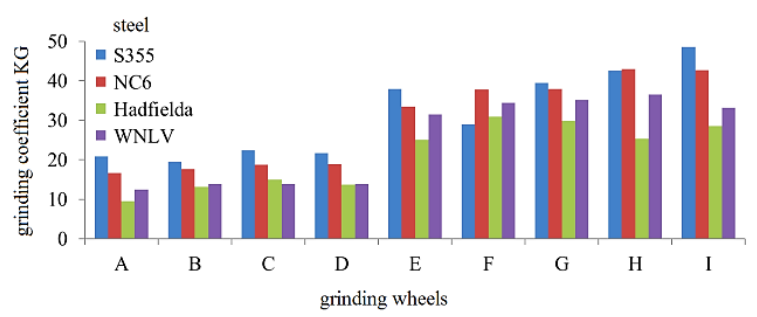

Fig. 4. The values of grinding coefficient KG.

As can be seen from Fig. 4, the lowest value of $\mathrm{KG}$ coefficient of grinding wheels was obtained during grinding of Hadfield steel. This means that this steel has the best abrasion resistance among the four abrasive materials. For the first four wheels, the value of the KG grinding coefficient of all steels is about half as high as for the other five grinding wheels. Grinding wheels B, C and D for individual steels show very similar values of KG coefficient. When NC6 steel is machined for each subsequent grinding wheel, the KG grinding coefficient increases.

\section{Conclusions}

On the basis of conducted tests, a comparative assessment of wear indicators of grinding wheels was found:

- during the tests of wheels used for metal grinding, it was found that S355 steel is the most susceptible to abrasive machining among the four grinded materials (Fig. 3),

- the lowest grinding efficiency of S355 steel was obtained for a C wheel (525 g) of 15 minutes process, while the highest efficiency for wheel I (1155 g),

- NC6 steel and Hadfield steel are characterized by high resistance to abrasion, and the effectiveness of their abrasion is the lowest for all tested grinding wheels,

- when grinding S235 steel, the best KG coefficient is distinguished by the wheel I (Fig. 4). The value of the KG coefficient is 48,53 . The worst results were obtained for grinding wheel B, where the value of KG coefficient equals 19,41,

- the value of the KG coefficient is the lowest for grinding of Hadfield steel (Fig.4),

- based on the calculated KG coefficient, it can be concluded that among all grinding wheels, a lower machining efficiency was obtained for wheels A, B, C, and D.

\section{References}

1. S. Malkin, Ch. Guo, Grinding technology: Theory and Applications of Machining with Abrasives, Industrial press (New York 2008)

2. M.J. Jackson, M.P. Hitchiner, High Performance Grinding and Advanced Cutting Tools (Springer Science+Business Media, New York 2013) 
3. Z.B. Hou, R. Komanduri, Int. J. of Mach. Tools \& Manuf. 43, 1579 (2003)

4. L.V. Hudobin, Proc. of the Ulyanovsk Polytechnic. Inst. 1, 19(1966)

5. V.M. Shumyachera, A.V. Slavina, B.M. Brzhozowskib, Procedia Eng. 150, 920 (2016)

6. J. Józwik, K. Dziedzic, I. Usydus, D. Ostrowski, G.M. Krolczyk, J. of Central South Univ. 25(5), 1144 (2018)

7. M. Novák, N. Náprstková, J. Józwik, Adv. in Science and Technol Res. J. 9(26), 41 (2015)

8. N. de Souza, R.E. Catai, P.R. de Aguiar, M.H. Salgado, E.C. Bianchi, J. of the Brazilian Society of Mech. Scie. and Eng. 2, 209 (2004)

9. C. Aurich, D. Biermann, H. Blum, Prod. Eng. 1, 111 (2009)

10. Z.D. Shi, M. Srinivasaraghavan, H. Attia, Key Eng. Mat. 1-6, 389 (2008)

11. B.W. Rowe, X. Chen, Proc. of the Inst. of Mech. Eng., Part B: J. of Eng. Manuf. 1, 93 (1999)

12. S.K. Kharea, A. Sanjay, Procedia CIRP 31, 375 (2015)

13. Y.K. Novoselov, S.M. Bratan, Bulletin of SevNTU, Series Mech. Eng. and Transport 118, 92 (2011).

14. W. Kacalak, M. Kasprzyk, T. Krzyzynski, Proc. Appl. Math. Mech. 2, 278 (2003)

15. S. Öztürk, M.F. Kahraman, Measurement 145, 274 (2019)

16. Y.K. Novoselov, S.M. Bratan, V.B. Bogutsky, Proc. Eng. 150, 809 (2016)

17. J. Borkowski, P. Borkowski, Arch. of Civil and Mech. Eng 1-2, 21 (2002)

18. D.V. Ardashev, Bulletin of the South Ural State University, Series Mech. Eng. Industry 4, 55 (2014)

19. I. D. Marinescu, Tribology of abrasive machining processes, (Brent Beckley, William Andrew, Inc. Cover Art 2004)

20. H., Hamdi, M., Dursapt, H. Zahouani, Wear 12, 1294 (2003)

21. Y.K. Novoselov, V.B. Bogutsky, Cutting \& tool in technological system 81, 228 (2012)

22. B.R. Warkentin, Transactions of the CSME/de la SCGM 27, 193 (2003)

23. Y.K. Novoselov, V.B. Bogutsky, Bulletin of SevNTU, Series Mech. Eng. and Transport 128, 23 (2012)

24. M. Ahrensa, J. Dammb, M. Dagena, B. Denkenab, T. Ortmaiera, Procedia CIRP 58, 422 (2017)

25. R. Neugebauera, K.U. Hessb, S. Gleicha, S. Popa, Int. J. of Machine Tools \& Manuf 45, 1120 (2005)

26. S. Devendiran, K. Manivannan, Int. J. of Eng. and Technol. 5, 4010 (2013)

27. K. Wegener, H.W. Hoffmeister, B. Karpuschewski, F. Kuster, W.C. Hahmann, M. Rabiey, CIRP Annals - Manuf. Technol. 60, 757 (2011)

28. J. Józwik, D. Mika, Adv. in Science and Technol. Res. J. 9(26), 57 (2015)

29. J. Józwik, Adv. in Science and Technol. Res. J. 10(30), 127 (2016)

30. A. Łukaszewicz, G, Skorulski. R. Szczebiot, In: Proc. 17th Int. Conf. on Eng. for Rural Develop. (Jelgava, Latvia), 865 (2018)

31. I. Mircheski A. Łukaszewicz, R. Szczebiot, Proc. Manuf. 32, 68 (2019)

32. A. Łukaszewicz, K. Panas R. Szczebiot, In: Proc. 17th Int. Conf. on Eng. for Rural Develop. (Jelgava, Latvia), 871 (2018)

33. R. Trochimczuk, A. Łukaszewicz, T. Mikołajczyk, F. Aggogeri, A. Borboni, Simulation Trans. Soc. Model. Simul. Int. DOI: 10.1177/0037549719835920 in press, (2019)

34. V.N. Paimushin, S.A. Kholmogorov, M.V. Makarov, D. Tarlakovskii, A. Lukaszewicz, Z. Angew. Math. Mech. 99(1), e201800063 (2019)

35. V.V. Barsukov, W. Tarasiuk, V.M. Shapovalov, B. Krupicz, V.G. Barsukov, J. Frict. Wear 38(1), 71 (2017)

36. A. Łukaszewicz, J. Frict. Wear 39(6), 476 (2018) 